\title{
CITY OF LOS ANGELES CORNFIELD ARROYO SECO SPECIFIC PLAN: PARKING MANAGEMENT STRATEGIES
}

A Professional Project Presented to the Faculty of

California Polytechnic State University, San Luis Obispo

Miriam Leah Thompson | Wednesday, July 24, 2013 
CHAPTER I Introduction

CHAPTER II Policy Review

CHAPTER III Best Practices

CHAPTER IV Literature Review

CHAPTER V Methodology

CHAPTER VI Data Analysis

CHAPTER VII Conclusion $\&$

Recommendations 


\section{CHAPTER I INTRODUCTION}

1. Geographic Location

2. Existing Conditions

3. Significance of the CASP

4. Study Purpose

5. Problem Statement 


\section{GEOGRAPHIC LOCATION}

The CASP is a 603-acre area bordered on the north and west by Interstate 110 (Pasadena Freeway) the Arroyo Seco waterway and Elysian Park.

Chinatown is immediately adjacent to its south-westernmost area. Directly south of the Plan area is Union Station, historic Olvera Street and the downtown Civic Center.

The Interstate 5 (Golden State Freeway) the Los Angeles River and Metrolink all pass through the plan area.

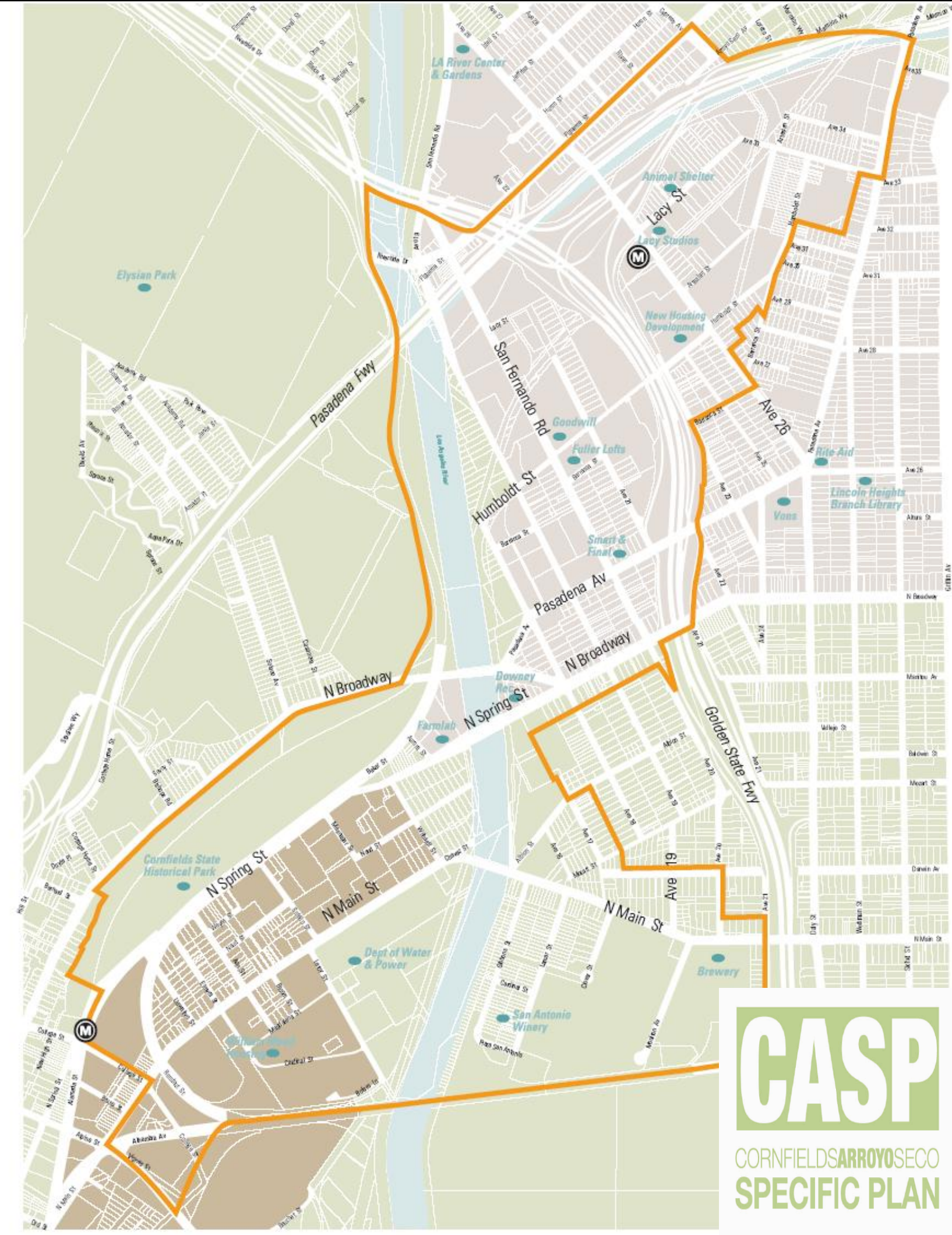




\section{EXISTING CONDITIONS}

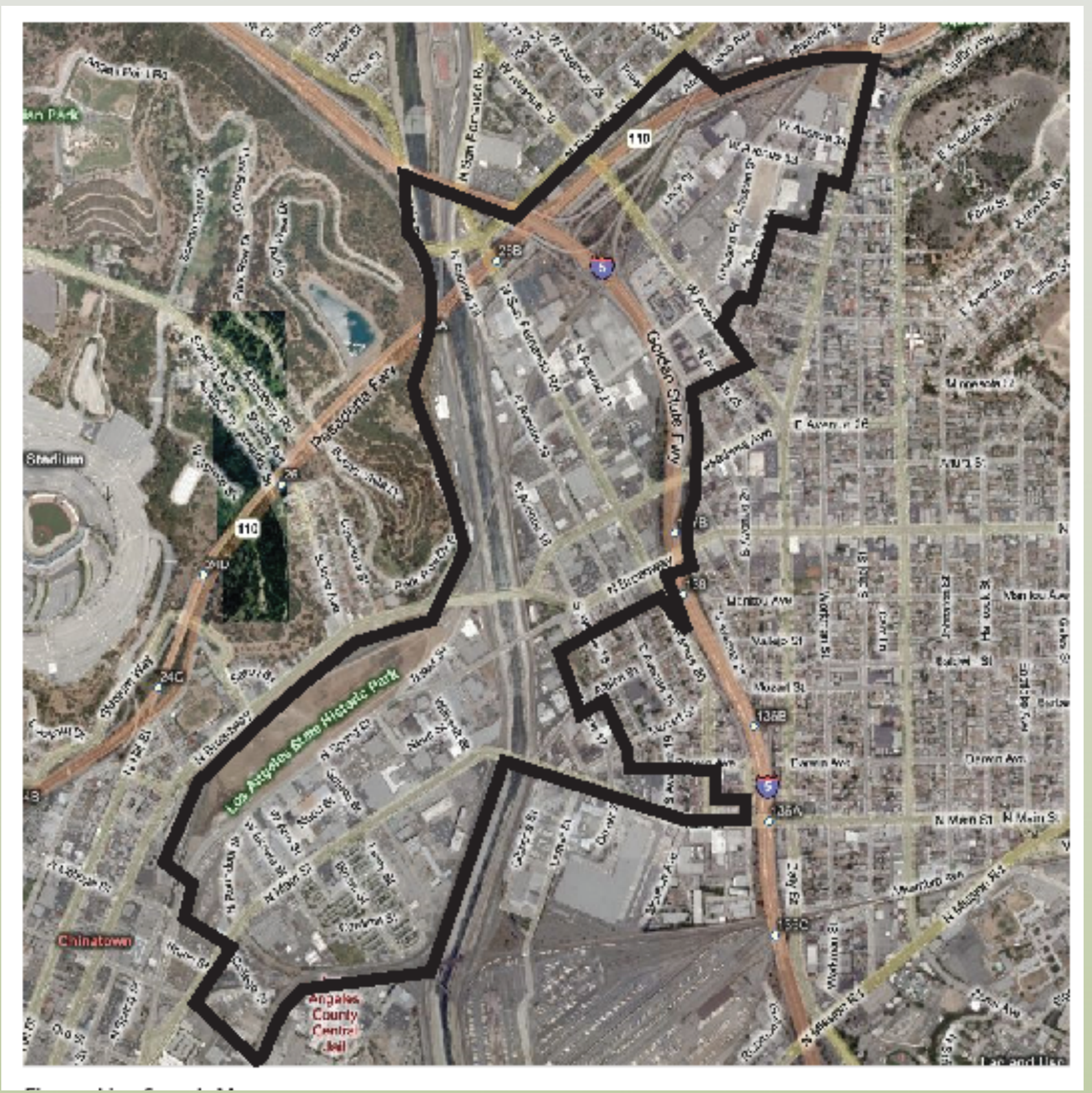




\section{SIGNIFICANCE OF THE CORNFIELD ARROYO SECO SPECIFIC PLAN}

The physical and cultural characteristics of the CASP area provide excellent opportunities to promote the healthy living benefits of integrates the principles of smart growth, New Urbanism, and green building into neighborhood design so that a level of sustainability can be attained for an the entire area. 
STUDY PURPOSE 


\section{CHAPTER II POLICY REVIEW}

1. The City of Los Angeles General Plan

2. The City Of Los Angeles Municipal (Zoning) Code

3. Zoning Administrator Division : Parking Reduction

4. CASP Parking Objectives, Goals and, Policies

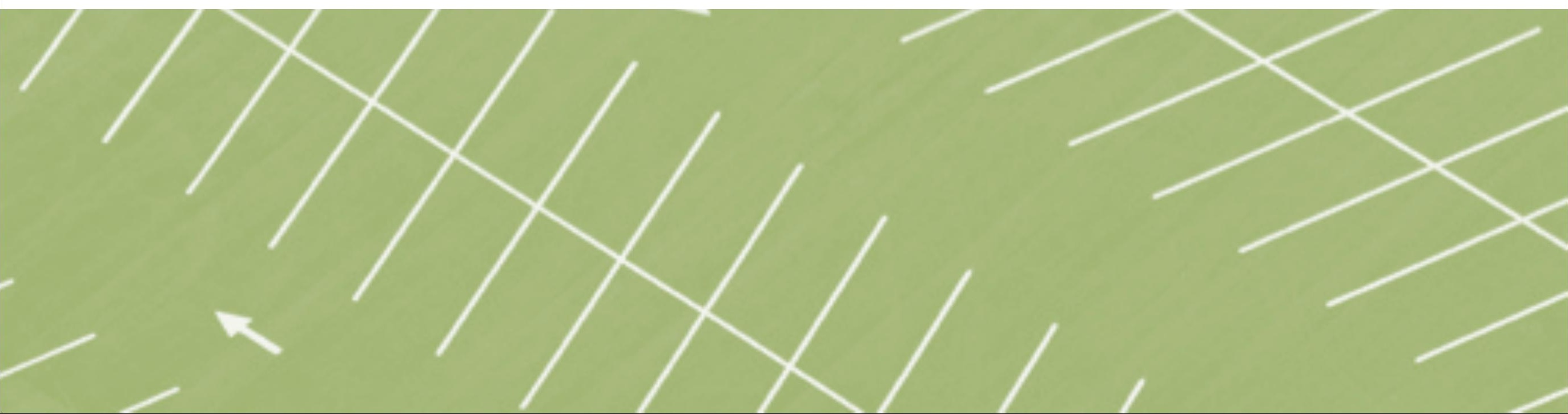




\section{City of los ANGeles General Plan}

The General Plan, readopted August 8, 2001, provides the overarching authoritative vision for the future of the city. A review of the General Plan Framework revealed that there are currently numerous goals, policies, and objectives that are aimed at improving the current state of parking. 


\section{CITY OF LOS ANGELES MUNICIPAL (ZONING) CODE}

Planning and Zoning, Chapter I of the Municipal Code, last amended by legislation effective April 30, 2009, spells out the detailed regulations that support the aforementioned General Plan goals, policies and objectives.

Chapter I Section. 12. 12. 1.'P' entitled "Automobile Parking Zone" in the zoning code provides numerical parking requirements for every use and zone. 


\section{ZONING ADMINISTRATOR DIVISION: PARKING REDUCTION}

Parking reductions are granted through a case-by-case evaluation. Determining which parking management alternative will satisfy both the ZAD and the applicants' needs is a joint effort between both parties.

The applicant can choose to provide a parking management plan with alternatives like remote offsite parking, shared parking, offsite parking, vanpools, carpools, bicycle racks, motorcycle parking, or discounted group transit passes for employees.

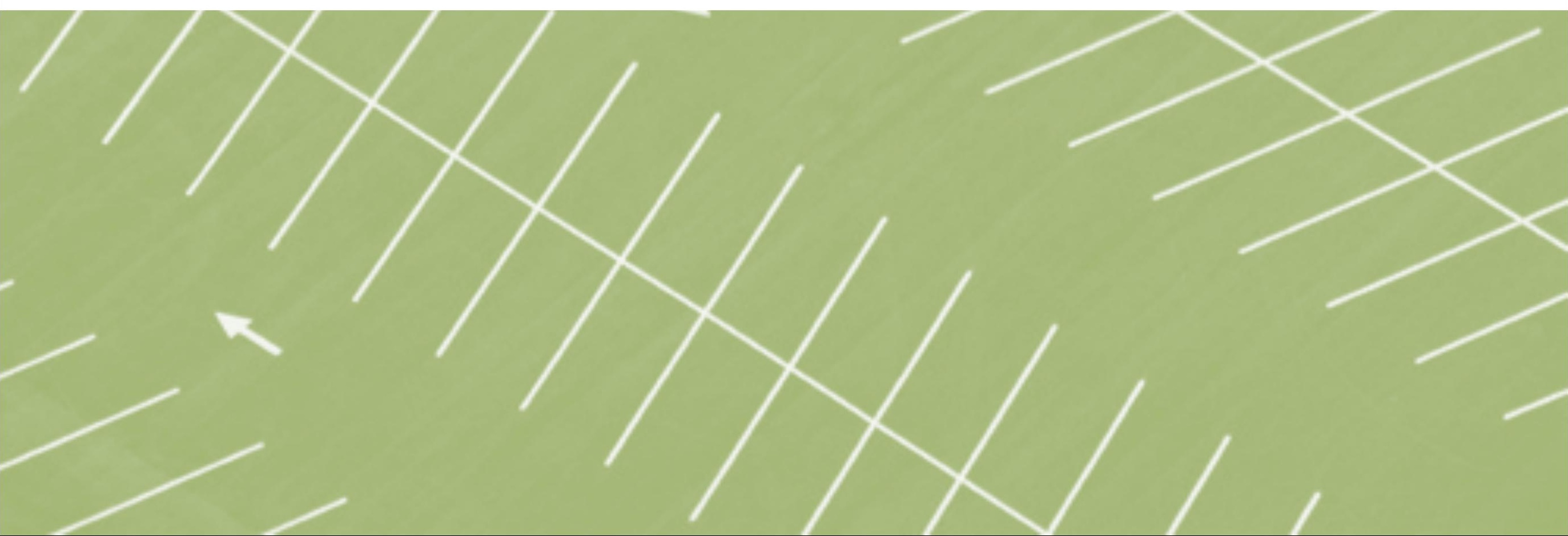




\section{CASP PARKING OBJECTIVES, GOALS AND, POLICIES}

The first plan of any kind in the city of Los Angeles that does not include parking requirements. The lack of parking requirements will allow developers to minimize the amount of parking for specific projects, given the neighborhood's proximity to transit, the changing culture of Los Angeles, and the declining need for parking.

The effect will be to let the market decide how much parking is needed and where.

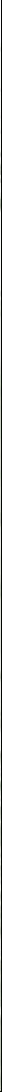




\section{UNBUNDLED PARKING}

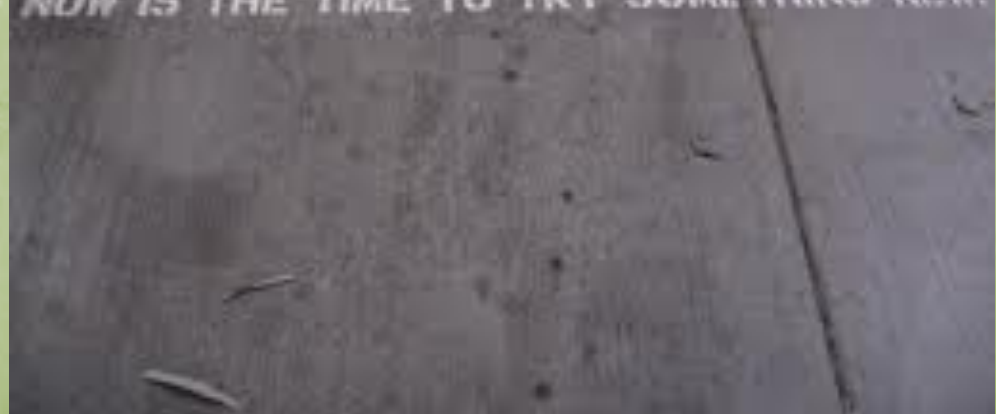

The proposed plan further requires developers to "unbundle" the parking from the rental or sale price of the unit or square footage. By unbundling the price of a vehicle parking space from the rent or sale price of a residential unit renters or home buyers who do not have a vehicle or who have less than two cars will be able to obtain a unit less expensively than in other places in the City where two parking spaces are typically included in the rent or sale price. 


\section{CHAPTER III BEST PRACTICES}

1. City of Santa Monica

2. The City of Pasadena

3. The City of Los Angeles

4. Comparison of Parking Policies 


\section{CITY OF SANTA MONICA}

The Santa Monica Municipal Code (SMMC) contains over a dozen strategies that regulate the provision of parking. All of these strategies are designed to work synergistically to enhance the overall vitality of the city. The SMMC includes

By far, the strategy that is on the leading edge is the innovative parking cash-out program. The city's cash out program is most frequently highlighted in scholarly literature as the superlative example of a municipal parking cash-out program.

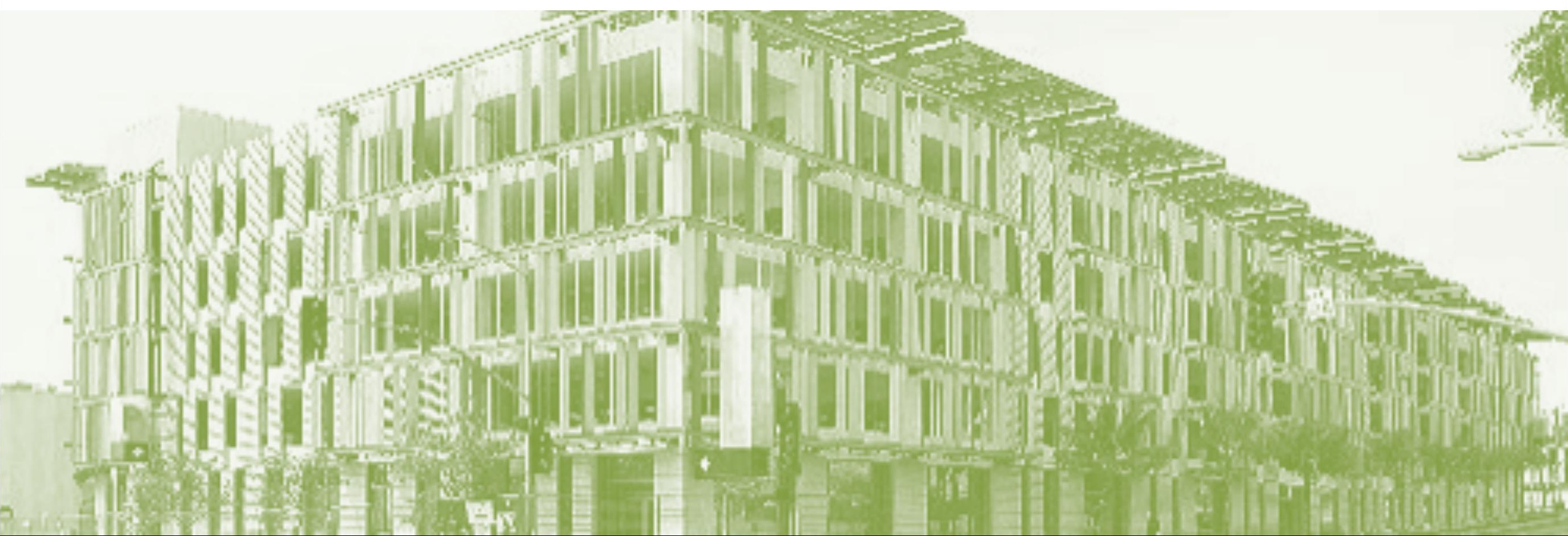




\section{THE City OF PASADENA}
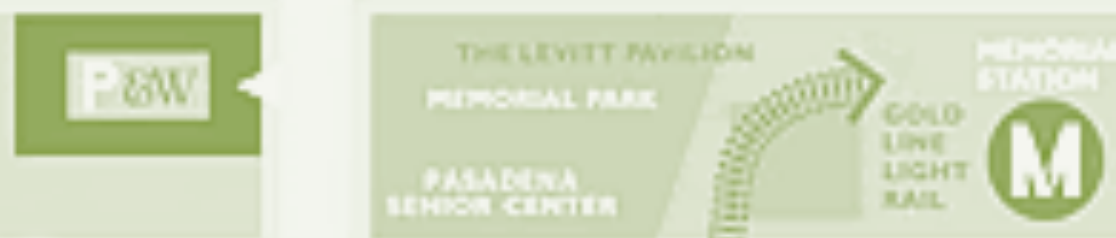

- Parking Benefits District,

- Parking Management Zone,

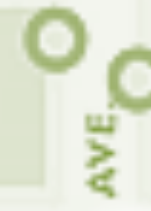

- Transit Oriented Development Parking Requirement Reduction,

- Parking Meter Zone (PMZ)

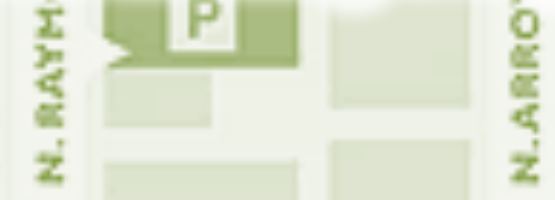

* Old Pasadena Business Improvement District (BID).
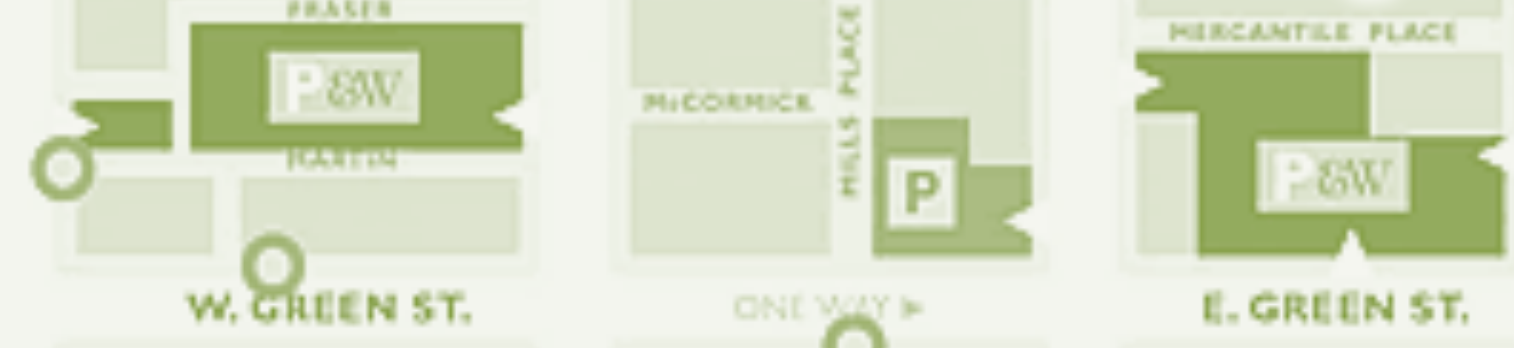


\section{MANAGEMENT STRATEGY}

Shared Parking

Off-Site Parking

Exemptions for Minor Floor Area Additions

Compact Spaces

Tandem and Stacked Spaces

Vanpool and Carpool Parking

Curb loading provisions

Parking cash-out

Reduced Parking Requirements

Shared / Joint Parking,

Minimum Parking Requirements

Change of Use

Tandem and Stacked Spaces

Bicycle Parking

Parking pricing and time restrictions

Park Once and Walk" outreach campaign

Transit park/ride parking facilities

Preferential parking district programs

Multispace meters

Business Improvement District

Parking Meter Zone

Parking Credit program

Trip Reduction Standards

TOD Parking Requirement Reduction

Unbundled Parking

\section{PARKING}

\section{POLICY}

\section{COMPARISON}

CHART 


\section{CHAPTER IV LITERATURE REVIEW}

1.Transportation and Land Use: A Perspective

2.The High Cost of Free Parking

3.Comparison of Parking Management Strategies

4. Guide on Parking Rates

5.Parking and Smart Growth Study

6.Transit Passes In Lieu Of Required Parking Spaces 


\section{TRANSPORTATION AND LAND USE: A PERSPECTIVE}

The voices of researchers, J.S. Adams (1970) and P.O. Muller (1995), have shaped the way the history of transportation and land use are viewed. Adams (1970) posits that "Transportation modes has shaped the pattern of urban form into four eras: the Walking/Horsecar era, the Electric Streetcar era, Recreational Automobile era, and the Freeway era. 


\section{THE HIGH COST OF FREE PARKING}

According to Donald Shoup (2005), most local governments, through their zoning ordinances, have a parking supply policy that requires land uses to provide minimum parking requirements based on the peak demand each use generates, without considering the cost to developers and end users.

He posits that this has encouraged automobile dependency and urban sprawl. As the old adage says, "there is no such thing as a free lunch". The same can be said for parking. The cost of "free parking" is actually bundled into a buildings' overall development, purchase and lease cost. A minimum parking requirement can increase development costs by more than 10 times 


\section{SCHOLARLY LITERATURE}

MANAGEMENT

STRATEGY

Transit/TOD Supportive Policies Carsharing

Transit Friendly Parking Design

Transit Supportive Zoning

Transit Incentive Programs

Walkability and Wayfinding

Late-night taxi service and feeder shuttl service

Transit subsidies for tenants

Guaranteed ride home program

Pedestrian and Bike amenities

Parking Requirements

Reduced Parking Requirement

TOD Friendly Parking Requirements

Parking Maximums

Shared Parking

Free parking for carpools and vanpools.

Demand-based parking requirements

based upon local use study

\section{Parking Pricing}

On-street Parking Pricing

Variable Rate Parking Pricing

Coordinated Off-street and On-street

Pricing

Unbundled Parking

Parking Cash-Out

Parking Management Strategies Parking Payment Technology

Parking Database

Real-time Parking Information

Designated transportation coordinator

Parking Districts

Assessment Districts

Revenue Districts

Residential Permit Parking

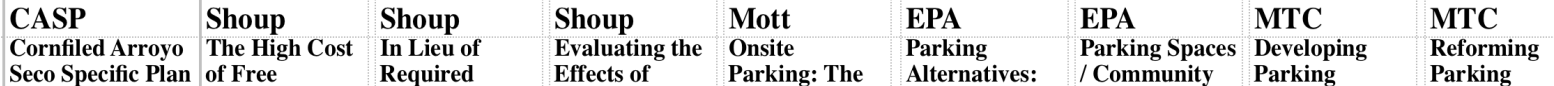

EPA EPA

MTC

MTC

Required

Effects of Parking: The

Parking Cash Scourge of

Case Studies Commercial

\begin{tabular}{ll|l|l}
\hline Alternatives: & Pammunity & Parking & Parking \\
\hline
\end{tabular}

for Urban Infill the Balance Support Smart Support Smatt

Case Studies Commercia

\begin{tabular}{|l|l|l|l|}
$\begin{array}{lll}\text { for Urban Infill } \\
\text { and }\end{array}$ & $\begin{array}{l}\text { the Balance } \\
\text { Through } \\
\text { Brownfields }\end{array}$ & $\begin{array}{l}\text { Support Smart } \\
\text { Smart Growth }\end{array}$ & $\begin{array}{l}\text { Support Sn in } \\
\text { Growth }\end{array}$ \\
\hline
\end{tabular}

Brownfields Smart Growth Local

Redevelopment Solutions

Jurisdictions:

PARKING MANAGEMENT

STRATEGIES

Parking Financing

In-Lieu Fees

Risk Fund

Parking Occupancy Ta

Parking Tax by Space

Tax Exemptions and Variable Rate Tax

\begin{tabular}{|c|c|c|c|c|c|c|c|c|}
\hline$v$ & & & & & & & $v$ & $v$ \\
\hline$\checkmark$ & & & & & & & $\checkmark$ & $\checkmark$ \\
\hline$v$ & & & & & & & $\checkmark$ & $\checkmark$ \\
\hline$v$ & & & & & $\checkmark$ & & $\checkmark$ & $\checkmark$ \\
\hline$v$ & & & & & & & & $\checkmark$ \\
\hline No & & & & & & & $v$ & \\
\hline No & & & $v$ & & & & $v$ & \\
\hline No & & & & & & & & \\
\hline$v$ & & & & & $\checkmark$ & & & \\
\hline$v$ & $v$ & $v$ & $v$ & $v$ & & $v$ & $v$ & $v$ \\
\hline$v$ & & & & & $v$ & & & $\checkmark$ \\
\hline No & & & & $v$ & & $v$ & $v$ & $\checkmark$ \\
\hline$v$ & & $v$ & & & $v$ & $v$ & $v$ & $v$ \\
\hline No & & & & & & & $\checkmark$ & \\
\hline$*$ & & & & & $v$ & & $v$ & \\
\hline$*$ & $v$ & & $\boldsymbol{v}$ & & & & $v$ & $v$ \\
\hline No & $v$ & & & & & & $v$ & $\checkmark$ \\
\hline$*$ & $v$ & & & & & & & $\checkmark$ \\
\hline$v$ & $v$ & $v$ & & & & & $v$ & $v$ \\
\hline$*$ & $v$ & & $v$ & & $v$ & & & $\checkmark$ \\
\hline No & & & & & & & & $v$ \\
\hline No & & & & & & & & $\checkmark$ \\
\hline No & & & $v$ & & & & & $v$ \\
\hline No & & & & & & & $v$ & \\
\hline No & $v$ & & $v$ & & & & $\boldsymbol{v}$ & $v$ \\
\hline No & $v$ & & $v$ & & & & $v$ & $v$ \\
\hline No & & & & & & & & $v$ \\
\hline No & & $v$ & & & $v$ & & $v$ & $v$ \\
\hline No & & & & & & & & $v$ \\
\hline No & & & & & & & & $v$ \\
\hline No & & & & & & & & $\checkmark$ \\
\hline No & & & & & & & & $v$ \\
\hline
\end{tabular}




\section{Policy/Program}

\section{Parking Pricing}

\section{Shared Parking}

\section{Reduced Parking Requirements}

\section{Unbundling and} Cash-Out Options

\section{Transit Passes and Incentives}

Car Sharing

Potential Effectiveness

(percent reduction in demand)

\section{Comments}

HIGH

Depending on the amount of the parking fee and the surrounding/controls on parking

\section{MEDIUM/HIGH TYPICALLY 10-20\%}

Depending on the mix of land uses and parking demand in relatively close proximity

MEDIUM TYPICALLY $10-15 \%$

Depending on how close the requirements are to actual demand rates

MEDIUM TYPICALLY 10-15\%

Depending on the price, demand and convenience of parking in the area

MEDIUM/LOW

TYPICALLY 5-10\%

Depending on how close the requirements are to actual demand rates. Depends on transit access + relative convenience between transit and destinations + pricelincome levels

\section{LOW}

TYPICALLY 3-5\%

Depending on the auto-ownership levels, density and level of mixed use development in the area, and transit quality
Pricing is known as the most effective way to manage parking demand. There are a number of specific approaches to address different settings.

Shared parking reductions can be readily calculated once the actual land use types are known.

Reduces the supply, which in turn may reduce demand, or reflect a lower demand, especially adjacent to transit or combined with shared parking and pricing.

This is really a variation of parking pricing and is quite effective. Can be used in both residential and work envir onments.

The costeffectiveness of these measures appears to be very good for development immediately adjacent to transit stations/corridors.

Car sharing supports lower household auto ownership rates, transit and other parking policies. It may indirectly contribute to greater reductions in demand. 


\section{EFFECTS OF CASHING OUT EMPLOYER PAID PARKING:}

- An employer-funded program under which an employer offers to provide a cash allowance to an employee equivalent to the parking subsidy that the employer would otherwise pay to provide the employee with a parking space.

- The cash-out law applies to employers who:

- Employ at least 50 persons;

- Subsidize commuter parking in parking spaces they do not own;

- Are located in a non-attainment air basin 


\section{ECO PASSES}

There is considerable evidence that providing Eco Passes instead of parking spaces will increase transit ridership, reduce the cost of transit oriented development, improve urban design, reduce the need for variances, and reduce traffic congestion, air pollution, and energy consumption. 


\section{CHAPTER V METHODOLOGY}

1. Secondary Data and Literature

2. Primary Data Collection

3. Dataset 1 Methods

4. Dataset 1 Shortcomings

5. Field Survey

6. Dataset 2 Methods

7. Dataset 2 Tools

8. Zone Three Study Site

9. Sampling Method 


\section{SCIENTIFIC BASIS OF THE STUDY ACTION}

\begin{tabular}{|l|l|}
\hline STEPS & ACTION \\
\hline 2. Hypothesis & $\begin{array}{l}\text { Conduct a physical field survey the parking supply \& demand in } \\
\text { the CASP area. }\end{array}$ \\
$\begin{array}{l}\text { The uses in the CASP do not generate parking demand consistent } \\
\text { with the parking requirements prescribed in the LA Municipal } \\
\text { zoning code, therefore there is an oversupply of parking in relation } \\
\text { to demand. }\end{array}$ \\
\hline 3. Predictions & $\begin{array}{l}\text { The data gathered will show a majority of the land uses in the } \\
\text { CASP area generate parking demand that is less than the current } \\
\text { supply and requirements of the LAMC. }\end{array}$ \\
\hline 4. Test & $\begin{array}{l}\text { Through a quantitative survey of a representative sample, } \\
\text { numerically prove the discrepancy between the distribution of } \\
\text { supply and demand. }\end{array}$ \\
\hline
\end{tabular}




\section{PRIMARY DATA COLLECTION}

The primary data collection methods were an aerial survey and a field survey.

The dataset one aerial survey was conducted using web-based mapping programs. The goal was to provide initial rough estimates of the existing parking supply
The goal of dataset two was to determine the occupancy rates of weekday versus weekend and peak versus off-peak parking lot usage. 


\section{ZONE THREE STUDY SITE \& SAMPLING METHOD}

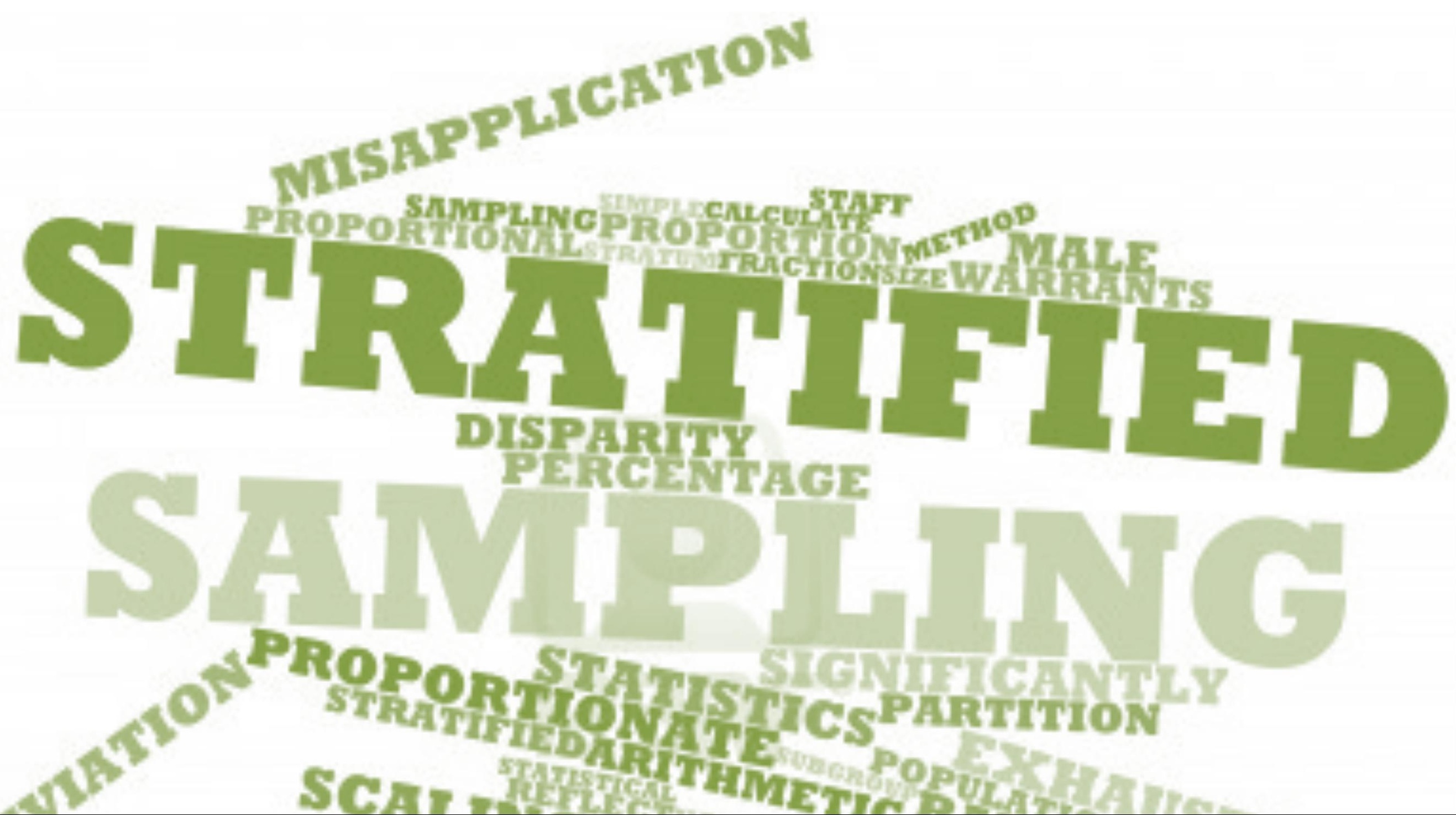




\section{CHAPTER VI DATA ANALYSIS}

1. Parking Supply

2. Parking Demand

3. Maximum Demand Observed

4. Young Nak Church Demand

5. Max Demand Weekday ws. Weekend 


\section{PARKING SUPPLY BY LAND USE}

\begin{tabular}{|c|c|c|}
\hline LAND USE & $\begin{array}{l}\text { Observed } \\
\text { Supply }\end{array}$ & $\begin{array}{l}\text { \% of Total } \\
\text { Supply }\end{array}$ \\
\hline $\begin{array}{l}\text { Multi Family } \\
\text { Residential }\end{array}$ & 27 & $2 \%$ \\
\hline $\begin{array}{l}\text { Single Family } \\
\text { Residential }\end{array}$ & 19 & $1 \%$ \\
\hline Residential TOTAL & 46 & $3 \%$ \\
\hline Service Shop & 57 & $3 \%$ \\
\hline Auto Service & 18 & $1 \%$ \\
\hline Warehouse $-10,000$ & 3 & $0 \%$ \\
\hline Light Manufacturing & 362 & $21 \%$ \\
\hline Public Facilities & 103 & $6 \%$ \\
\hline Restaurant & 12 & $1 \%$ \\
\hline Commercial & 367 & $21 \%$ \\
\hline $\begin{array}{l}\text { Church ( } 6000 \\
\text { members) }\end{array}$ & 768 & $44 \%$ \\
\hline Other Uses TOTAL & 1,690 & $97 \%$ \\
\hline All Uses TOTAL & 1,736 & $100 \%$ \\
\hline
\end{tabular}




\section{PARKING SUPPLY (LAMC VS. OBSERVED)}

\begin{tabular}{|c|c|c|c|c|}
\hline LAND USE & $\begin{array}{l}\text { Zoning } \\
\text { Requirement }\end{array}$ & $\begin{array}{l}\text { Spaces } \\
\text { Required by } \\
\text { Zoning }\end{array}$ & $\begin{array}{l}\text { Observed } \\
\text { Supply Ratio } \\
\text { / 1,000 sf }\end{array}$ & $\begin{array}{l}\text { Observed } \\
\text { Supply }\end{array}$ \\
\hline $\begin{array}{l}\text { Multi Family } \\
\text { Residential }\end{array}$ & $2 / \mathrm{du}$ & 20 & 2.7 & 27 \\
\hline $\begin{array}{l}\text { Single Family } \\
\text { Residential }\end{array}$ & $1.5-2 / \mathrm{du}$ & 18 & 1.9 & 19 \\
\hline $\begin{array}{l}\text { Residential } \\
\text { TOTAL }\end{array}$ & & 38 & & 46 \\
\hline Service Shop & $1 / 500 \mathrm{sf}$ & 92 & 1.2 & 57 \\
\hline Auto Service & $1 / 500 \mathrm{sf}$ & 14 & 0.8 & 18 \\
\hline $\begin{array}{l}\text { Warehouse - } \\
10,000\end{array}$ & $\begin{array}{c}1 / 500 \mathrm{sf}+1 \\
/ 5000 \mathrm{sf}\end{array}$ & 4 & 0.4 & 3 \\
\hline $\begin{array}{l}\text { Light } \\
\text { Manufacturing }\end{array}$ & $1 / 500 \mathrm{sf}$ & 384 & 1.4 & 362 \\
\hline Public Facilities & $1 / 500 \mathrm{sf}$ & 491 & 0.3 & 103 \\
\hline Restaurant & $1 / 100 \mathrm{sf}$ & 6 & 20.8 & 12 \\
\hline Commercial & $1 / 250 \mathrm{sf}$ & 196 & 0.9 & 367 \\
\hline $\begin{array}{l}\text { Church ( } 6000 \\
\text { members) }\end{array}$ & $\begin{array}{c}1 / 35 \text { or } 1 / 5 \\
\text { seats }\end{array}$ & 1200 & 3.1 & 768 \\
\hline $\begin{array}{l}\text { Other Uses } \\
\text { TOTAL }\end{array}$ & & 2,388 & & 1,690 \\
\hline All Uses TOTAL & & 2,425 & & 1,736 \\
\hline
\end{tabular}




\section{MAXIMUM DEMAND OBSERVED}

\begin{tabular}{|c|c|c|}
\hline LAND USE & $\begin{array}{c}\text { Observed Max } \\
\text { Demand }\end{array}$ & \% of Supply \\
\hline $\begin{array}{c}\text { Multi Family Residential } \\
\text { Single Family Residential }\end{array}$ & 17 & $63 \%$ \\
\hline Residential TOTAL & 20 & $105 \%$ \\
\hline Service Shop & 37 & $80 \%$ \\
\hline Auto Service & 56 & $98 \%$ \\
\hline Warehouse -10,000 & 14 & $78 \%$ \\
\hline Light Manufacturing & 3 & $100 \%$ \\
\hline Public Facilities & 246 & $68 \%$ \\
\hline Restaurant & 66 & $64 \%$ \\
\hline Commercial (freestanding discount) & 13 & $108 \%$ \\
\hline Church (6000 members) & 264 & $72 \%$ \\
\hline Other Uses TOTAL & 769 & $100 \%$ \\
\hline All Uses TOTAL & $\mathbf{1 , 4 3 1}$ & $\mathbf{8 5 \%}$ \\
\hline
\end{tabular}




\section{MAX DEMAND WEEKDAY VS. WEEKEND}

\begin{tabular}{|c|c|c|c|c|}
\hline LAND USE & $\begin{array}{l}\text { Weekday } \\
\text { Max } \\
\text { Demand }\end{array}$ & $\begin{array}{l}\% \text { of } \\
\text { Supply }\end{array}$ & $\begin{array}{l}\text { Weekend } \\
\text { Max } \\
\text { Demand }\end{array}$ & $\begin{array}{l}\% \text { of } \\
\text { Supply }\end{array}$ \\
\hline $\begin{array}{l}\text { Multi Family } \\
\text { Residential }\end{array}$ & 11 & $41 \%$ & 17 & $63 \%$ \\
\hline $\begin{array}{l}\text { Single Family } \\
\text { Residential }\end{array}$ & 20 & $105 \%$ & 20 & $105 \%$ \\
\hline Residential TOTAL & 31 & $67 \%$ & 37 & $80 \%$ \\
\hline Service Shop & 56 & $98 \%$ & 26 & $46 \%$ \\
\hline Auto Service & 14 & $78 \%$ & 10 & $56 \%$ \\
\hline Warehouse $-10,000$ & 3 & $100 \%$ & 1 & $33 \%$ \\
\hline Light Manufacturing & 232 & $64 \%$ & 246 & $68 \%$ \\
\hline Public Facilities & 66 & $64 \%$ & 24 & $23 \%$ \\
\hline Restaurant & 12 & $100 \%$ & 13 & $108 \%$ \\
\hline $\begin{array}{l}\text { Commercial } \\
\text { (freestanding } \\
\text { discount) }\end{array}$ & 264 & $72 \%$ & 233 & $63 \%$ \\
\hline Church & 139 & $18 \%$ & 769 & $100 \%$ \\
\hline Other Uses TOTAL & 786 & $47 \%$ & 1,322 & $78 \%$ \\
\hline ALL USES TOTAL & 817 & $47 \%$ & 1,359 & $78 \%$ \\
\hline
\end{tabular}




\section{WEEKDAY VS. WEEKEND DEMAND}

\begin{tabular}{|c|c|c|}
\hline \multirow{5}{*}{ 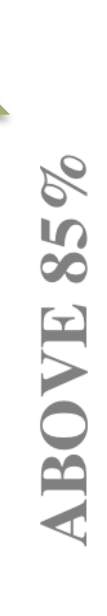 } & Weekday Demand & Weekend Demand \\
\hline & Single Family Residential & Church \\
\hline & Service Shop & Single Family Residential \\
\hline & Restaurant & Restaurant \\
\hline & Warehouse & \\
\hline & Auto Service & Auto Service \\
\hline 80 & Church & Commercial \\
\hline 3 & Commercial & Light Manufacturing \\
\hline$\overbrace{}^{0}$ & Light Manufacturing & Multi-Family Residential \\
\hline 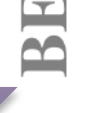 & Multi-Family Residential & Warehouse \\
\hline & Public Facilities & Public Facilities \\
\hline
\end{tabular}




\title{
CHAPTER VII RECOMMENDATIONS
}

\author{
7.1 Conclusion
}

7.2 Recommendations

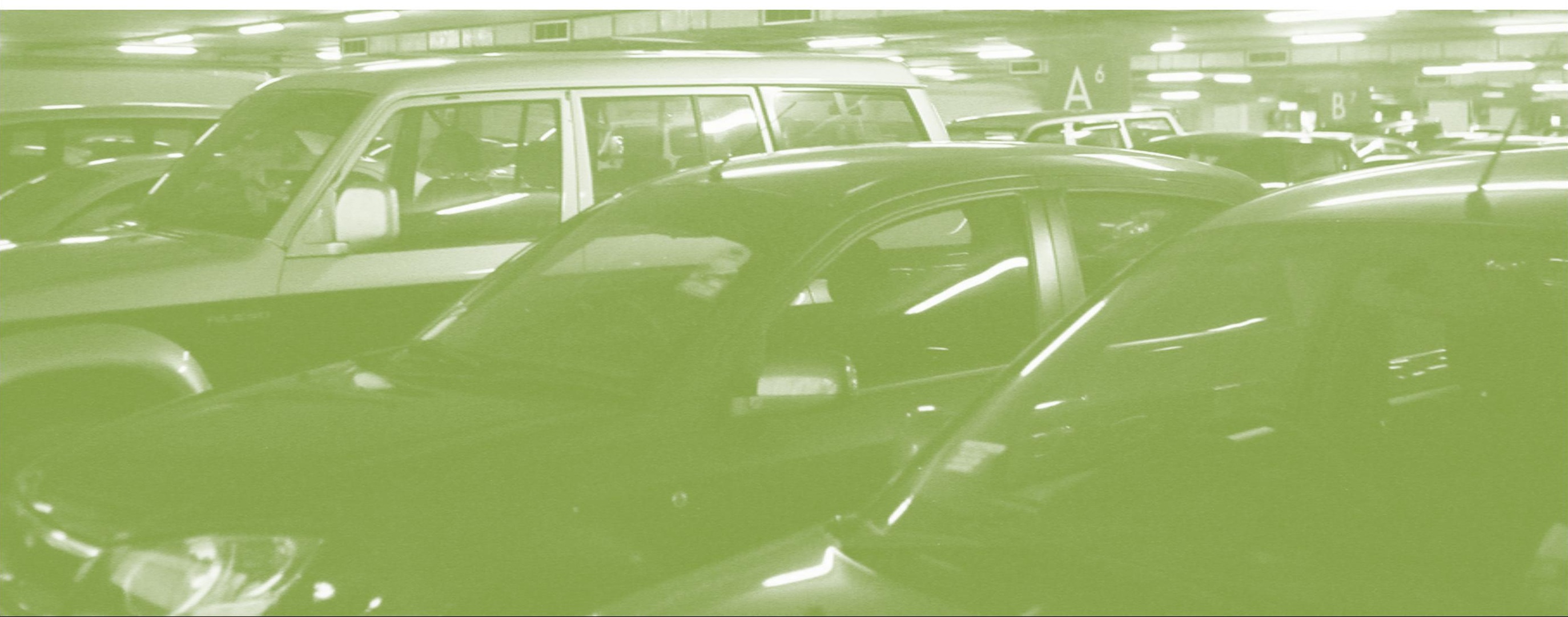




\section{CASP POLICIES}

\section{1) Car Sharing,}

2) Transit Friendly Parking Design,

3) Transit Supportive Zoning,

4) Transit Incentive Programs,

5) Walk Ability And Wayfinding,

6) Unbundled Parking

7) Pedestrian And Bicycle Amenities,

8) Reduced Parking Requirements

9) TOD Friendly Parking Requirements

10) Shared Parking 


\section{TRANSIT PASSES}

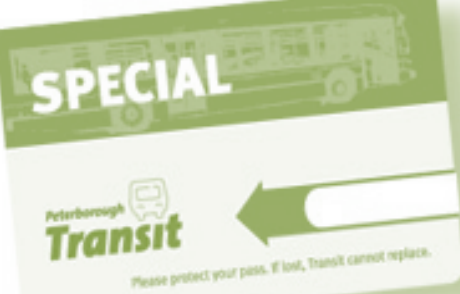

The CASP should require employers to provide discount transit passes for employees. Providing Eco Passes

The Eco Passes can yield benefits for developers, property owners, employers, commuters, transit agencies, and cities.

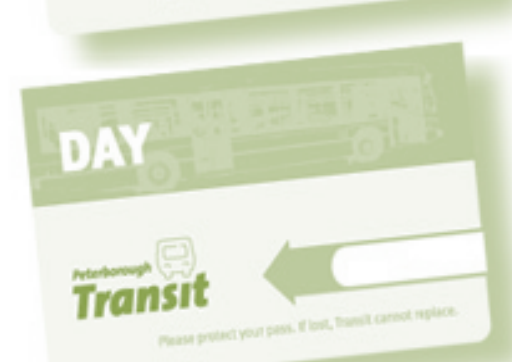

10 RIDE

\section{Transit}

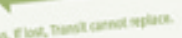
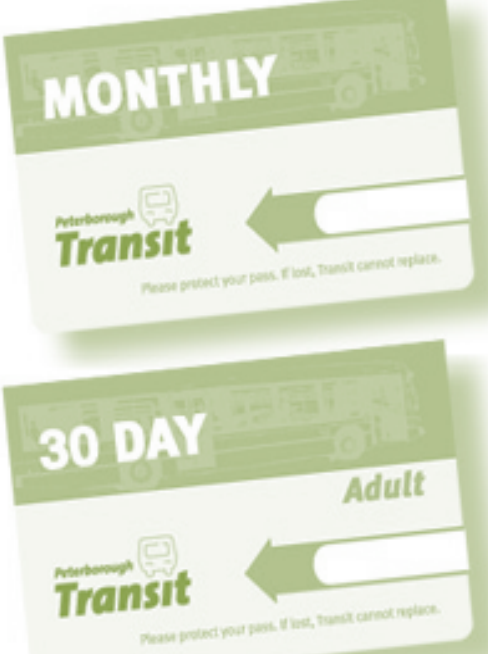

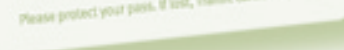

SINGLE RIDE

Transit 


\section{PARKING CASH OUT}

A study on parking cash-out summarized results from seven work sites and estimated a 26 percent reduction in parking demand. After cashing out, solo driving to work fell by 17 percent. Carpooling increased by 64 percent. Transit ridership increased by 50 percent. Walking and bicycling increased by 33 percent. Commute parking demand fell by 11 percent (Shoup, 1992) 


\section{SUMMARY}

- Both transit passes and parking cash out are cost effective because it is much cheaper to pay for a transit ride to and from work than to pay for a free parking space at work.

- The low cost of reducing the demand for parking compared with the high cost of increasing the supply shows that Eco Passes and parking cash out are cost-effective strategies.

- These cost-effectiveness comparisons were made in places famous for their addiction to cars: Silicon Valley (for Eco Passes) and Southern California (for parking cash out). If Eco Passes and parking cash out can reduce parking demand in these two places, they can probably achieve the same results the CASP area. 